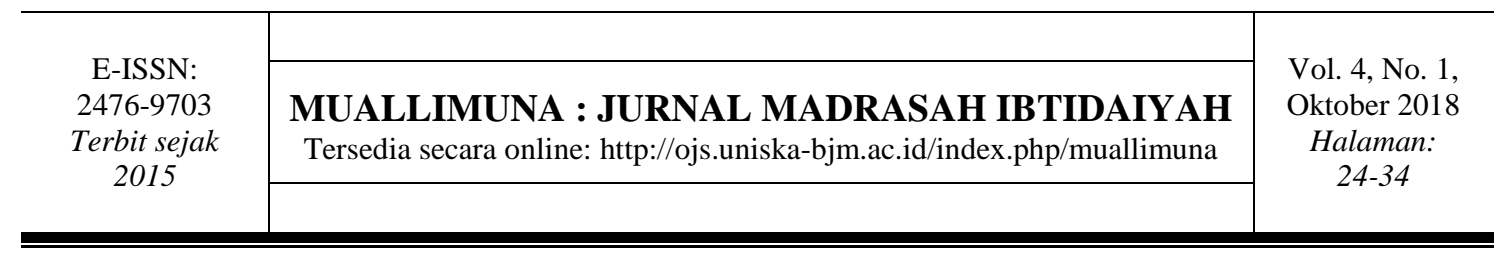

\title{
PENGEMBANGAN PERMAINAN TRADISIONAL BOI-BOIAN DALAM MENANAMKAN POLA PIKIR SAINS ANAK SEKOLAH DASAR
}

\author{
Efi Tri Astuti \\ Pendidikan Guru Madrasah Ibtidaiyah, STIT Muhammadiyah Pacitan \\ efitriastuti@gmail.com
}

\begin{abstract}
Abstrak: Tujuan penelitian ini adalah untuk mengetahui tahapan dan hasil penerapan pengembangan strategi pembelajaran permainan tradisional boi-boian dalam menanamkan pola pikir sains anak sekolah dasar.Desain pengembangan yang diterapkan peneliti adalah desain research and development yang dikembangkan oleh $\mathrm{R}$. Walter Gall, JP. Gall dan WR. Borg. Hasil analisis kebutuhan menunjukkan: strategi pembelajaran yang dipilih guru lebih menekankan pada metode ceramah, dikte dan hafalan sehingga belum mampu menanamkan pola pikir sains secara maksimal. Pola pikir peserta didik cenderung pasif; Guru belum pernah menerapkan strategi pembelajaran kooperatif; Pengujian perbedaan hasil evaluasi penggunaan strategi dengan independent sample t-test menunjukkan hasil bahwa terdapat perbedaan nilai yang signifikan antara kelas kontrol dan kelas eksperimen, yaitu dengan nilai t hitung $>$ dari pada $t$ tabel $(2,226>2,015)$ dan $\mathrm{P}$ value $(0,03<0,05)$ dengan rata-rata nilai kelas kontrol dan kelas eksperimen $(78.96<82.57)$, serta dinyatakan lebih aktif dalam hal mengamati, menanya, berargumen, mendengarkan dan kepercayaan diri.
\end{abstract}

Kata Kunci: strategi; permainan boi-boian; pola pikir sains; sekolah dasar

\section{DEVELOPING TRADITIONAL GAME OF BOI-BOIAN TO IMPLANT SCIENTIFIC THINKING IN CHILDREN OF ELEMENTARY SCHOOL}

\begin{abstract}
This research doing aimed to know the developing stage and the result of implementing the development traditional game boi-boian as an strategy to implant scientific thinking in children of elementary school. The implementation design from the researcher here is research and development version Borg and Gall consists of 10 stages. Analysis result needed from teachers and students shows that: teaching strategies selected more emphasis on lecturing, dictation and memorization methods, so as not to be able to implant the scientific thinking to the fullest. Mindset learners tend to be passive, the teacher never implemented cooperative learning strategie. The calculation using independent sample t-test shows the result that there is significant difference of the value between the control class and the experiment class, that is the $t$ count is greater than $t$-table $(2,226>2,015)$ and $P$ value $(0,03<0,05)$, and the average control and experiment class $(78.96<82.57)$ andexperiment class is more active.
\end{abstract}

Keywords: strategy; boi-boian game; scientific thinking; elementary school 


\section{PENDAHULUAN}

Indonesia adalah salah satu negara yang dikenal kaya akan kebudayaannya. Tiga unsur penting dalam kebudayaan meliputi kebudayaan sebagai suatu tata kehidupan, suatu proses, dan sesuatu yang memiliki visi tertentu (Suryana dan Rusdiana, 2015: 84). Menurut J.J. Honigmann yang dikutip oleh Yaya S. dan Rusdiana, wujud kebudayaan dibedakan menjadi tiga, yaitu wujud ide (ideas), wujud perilaku (activities), dan wujud artefak (artifact). Di Kabupaten Pacitan yang notabene adalah sebagai kabupaten dikawasan perbatasan, masih memiliki mayoritas masyarakat yang peduli terhadap budaya. Hal yang sederhana dapat peneliti amati (berdasarkan hasil observasi awal) adalah masih banyak anak-anak usia sekolah dasar yang memainkan permainan tradisional, salah satunya adalah permainan boi-boian yang dianggap mampu memberikan good value terhadap para pemainnya. Beberapa good value diantaranya adalah berlatih berorganisasi, berlatih merumuskan suatu strategi untuk menang, berlatih berkomunikasi antar anggota tim, berlatih untuk bekerja sama, dan berlatih untuk bermain secara sportif.

Pola pikir atau yang sering disebut dengan istilah mindset merupakan cara berpikir yang mempengaruhi perilaku dan sikap seseorang dalam hal problem solving. Pola pikir seseorang terbentuk dan dipengaruhi oleh kondisi emosional, pengalaman dan pengetahuan. Pola pikir yang digunakan dalam kehidupan sehari-hari (Hidayatno, 2013) terdiri atas berpikir logis, berpikir kritis, berpikir holistik dan berpikir lateral. Sedangkan pola pikir sains merupakan cara berpikir tentang suatu permasalahan yang menekan pada standar-standar sains, yaitu melalui tahapan observasi / pengamatan, penghimpunan informasi, pengkajian, dan penarikan simpulan terhadap suatu masalah.

Hasil observasi awal pada 3 lembaga pendidikan dasar di Kabupaten Pacitan menunjukkan bahwa proses pembelajaran sains masih cenderung pada pengembangan aspek intelektual dengan menggunakan buku guru sebagai bahan acuan utama dan menghafal sebagai metode pembelajaran yang diterapkan. Beberapa kelemahan dari penerapan metode menghafal antara lain: (1) konsep berpikir peserta didik cenderung statis karena peserta didik hanya mengetahui materi-materi yang dihafalkannya saja; (2) mayoritas dari mereka tidak dapat berargumen lebih selain dari materi yang mereka hafalkan; (3) peserta didik kesulitan untuk mengungkapkan ide-idenya; (4) metode menghafal juga menyebabkan tingginya tingkat stress peserta didik; (5) metode menghafal dinilai kurang efektif dalam menanamkan pola pikir sains pada diri peserta didik. Metode ini juga dianggap tidak efektif untuk memacu anak dalam berpikir kritis dan kreatif yang merupakan salah satu bentuk penanaman pola pikir sains.

Sebagai upaya untuk mengatasi kelemahan dari metode hafalan dalam pembelajaran sains tersebut maka perlu untuk melakukan penelitian dan pengembangan (research and development) berupa pengembangan strategi pembelajaran. Dengan memanfaatkan kebiasaan anak-anak dalam memainkan permainan tradisional boi-boian, maka perlu adanya pengembangan strategi pembelajaran yang berimplikasi pada skenario pembelajaran yang dilakukan, yaitu strategi permainan tradisional dalam menanamkan pola pikir sains anak sekolah dasar. Hal ini dirasa penting untuk diteliti dan dikembangkan, terlebih lagi dengan kurang mendukungnya fasilitas pembelajaran sains di lembaga pendidikan dasar dalam menerapkan kurikulum 2013.

Menurut Sanjaya (2007) strategi pembelajaran diartikan sebagai perencanaan yang berisi tentang kegiatan yang didesain untuk mencapai tujuan pendidikan tertentu. Sedangkan menurut Dick and Carrey (1985) strategi adalah satu set materi dan prosedur pembelajaran yang digunakan secara bersama-sama untuk menumbulkan hasil belajar 
siswa. Dalam menentukan strategi pembelajaran, guru harus mempertimbangkan beberapa aspek. Salah satunya adalah tahapan perkembangan kognitif anak. Berdasarkan teori perkembangan kognitif yang diprakarsai oleh Jean Piaget (baca: Zong Piazee),anak usia sekolah dasar masuk ke dalam kategori tahapan Operasional Konkret (usia 7-11 tahun). Tahap ini dicirikan dengan perkembangan system pemikiran yang didasarkan pada aturan-aturan yang logis. Proses-proses penting selama tahapan ini adalah sebagai berikut: (a) Pengurutan, (b) Klasifikasi; (c) Decentering; (d) Reversibility, (e) Konservasi; (f) Penghilangan sifat Egosentrisme.

Dunia anak sebagai dunia belajar sambil bermain telah banyak mengenalkan konsep permainan tradisional. Berdasarkan pendapat para ahli diberbagai sumber, penulis dapat menarik simpulan bahwa permainan tradisional merupakan permainan mendidik (game education) yang diwariskan secara turun-temurun sebagai identitas kebudayaan.Salah satu permainan tradisional yang masih melekat dalam kehidupan anak-anak adalah permainan tradisional boi-boian. Menurut Sri Mulyani permainan boiboian disebut juga permainan pecah piring yang dimainkan secara berkelompok. Boiboian merupakan permainan tradisional yang berasal dari provinsi Jawa Barat khususnya di daerah Sunda (Agus, 2014 : 1).Ada beberapa karakteristik permainan boiboian, yaitu: (1) Menggunakan pecahan genting dan bola kasti atau plastik untuk bermain; (2) Permainan dilakukan secara group, yaitu group main dan group lawan; (3) Dinyatakan menang apabila group main mampu menyusun kembali menara pecahan genting; (4) Dinyatakan kalah apabila semua pemain group main terkena lemparan bola dari pemain group lawan sebelum menara berhasil disusun (Sri Mulyani, 2013 : 29).

Richard dan Linda dalam bukunya yang berjudul The Thinker's Guide to Scientific Thinking (2012:3) mengemukakan bahwa:

"Scientific thinking is that mode of thinking - about any scientific subject, content, or problem - in which the thinker improves the quality of his or her thinking by skillfully taking charge of the structures inherent in thinking and imposing intellectual standards upon them. The Result: A well cultivated scientific thinker: raises vital scientific questions and problems, formulating them clearly and precisely; gathers and assesses relevant scientific data and information, using abstract ideas to interpret them effectively; comes to wellreasoned scientific conclusions and solutions, testing them against relevant criteria and standards; thinks openmindedly within convergent systems of scientific thought, recognizing and assessing scientific assumptions, implications, and practical consequences; and communicates effectively with others in proposing solutions to complex scientific problems".

Unsur pola pikir sains (Linda Elder dan Richard, 2012 : 4) terbagi menjadi 8, yaitu: purpose of scientific thinking, scientific question at issue, scientific information, scientific interpretation and inferences, scientific concepts, scientific assumptions, scientific implication and consequences, scientific point of view. Pola pikir sains harus memenuhi standart intelektual universal, yang meliputi : standards clarity (kejelasan); accuracy (ketelitian); depth (kedalaman); breadth (luas cakupan); significance (signifikan); precision (ketepatan); relevance (relevansi); fairness (keadilan).

Penanaman pola pikir sains terhadap anak usia sekolah dasar dapat ditanamkan melalui pendekatan saintifik yang terdiri atas sintaks 5 M, yaitu Mengamati, Menanya, Mengumpulkan Infomasi, Menalar dan Mengomunikasikan. Konsep pendekatan saintifik dimaksudkan agar peserta didik terlatih berpikir HOTS. Higher Order Thinking Skills (HOTS)atau sering dikenal dengan berpikir tingkat tinggi adalah suatu pola 
berpikir siswa yang bertumpu pada kemampuan untuk menganalisis, mencipta, dan mengevaluasi semua aspek tentang permasalahan. Prinsip dasar dari pembelajaran berbasis higher order thingking adalah berpikir kristis, berpikir kreatif, dan mengembangkan keahlian (King FJ : 1).

\section{METODE}

Model pengembangan yang digunakan dalam penelitian dan pengembangan ini adalah model pengembangan Borg \& Gall. Mengacu pada definisi tentang penelitian dan pengembangan menurut Borg \& Gall adalah suatu proses yang digunakan untuk mengembangkan atau memvalidasi produk yang digunakan dalam pendidikan (Sri Sumarni, 2015). Adapun tahapan penelitian dan pengembangan yang dilakukan adalah sebagai berikut: (1) research and information collecting; (2) planning; (3) develop preliminary form of the product; (4) preleminary field testing; (5) main product revision; (6) main field testing; (7) opertion product revision; (8) operational field testing; (9) final product revision; (10) dissemination and implementation.

Teknik pengumpulan data dalam penelitian dilakukan dengan wawancara, observasi, dan penyebaran angket. Pengujian efektivitas hasil pengembangan dilakukan dengan menggunakan desain eskperimen semu (quasi experiment), yaitu post-test only, non equivalent control group design. Metode analisis data yang digunakan terdiri atas analisis kualitatif dan kuantitatif. Motode analisis yang digunakan dalam penelitian ini adalah uji beda independent sample t-test.

Untuk menghindari kesalahan penafsiran dalam penelitian ini, penelitian ini dilaksanakan di SD Negeri Ngadirejan Kecamatan Pringkuku Kabupaten Pacitan. Penelitian dilakukan terhadap peserta didik Kelas IV A dan Kelas IV B dengan jumlah sampel sebanyak 46 peserta didik.

\section{HASIL DAN PEMBAHASAN \\ Hasil}

Hasil analisis kebutuhan guru dan peserta didik menunjukkan bahwa: (1) Ketidak tersediaan laboratorium dan alat praktikum menjadi hambatan bagi guru untuk menekankan pendekatan saintifik selama proses pembelajaran, sehingga strategi pembelajaran yang dipilih oleh guru adalah strategi yang menggunakan metode ceramah, dikte, dan hafalan; (2) Soal evaluasi yang diberikan oleh guru disetiap akhir pembelajaran masih menekankan pada ranah C1 (Pengetahuan), C2 (Pemahaman), C3 (Aplikasi); (3) Guru belum pernah menerapkan strategi pembelajaran kooperatif; (4) Karakter peserta didik selama proses pembelajaran diantaranya adalah mayoritas peserta didik merasakan tegang dalam pembelajaran, peserta didik cenderung pasif, takut untuk bertanya, takut untuk menyatakan pendapat, kesulitan untuk menuliskan simpulan dari materi pembelajaran, memiliki kebiasaan dan gaya belajar untuk selalu menghafal dan dikte materi, serta kebiasaan bermain peserta didik yang selalu terbawa pada saat proses pembelajaran dimulai.

Setelah melalui tahapan validasi produk oleh ahli dan juga pelaksanaan uji terbatas serta uji lapangan, didapatkan hasil pengembangan produk permainan tradisional boi-boian sebagai strategi pembelajaran sebagai berikut: 
Tabel 1: Hasil Pengembangan Permainan Boi-boian Sebagai Strategi Pembelajaran

Permainan Tradisional Boi-boian

1. Menyiapkan batu-batu pipih atau pecahan genting kira-kira sebanyak 10 keping.

2. Menyiapkan 1 bola menggunakan bola tenis) sebagai alat untuk meruntuhkan menara.

3. Tim dibagi menjadi 2 kelompok, yaitu tim bermain dan tim berjaga. Setiap tim terdiri atas 2-10 anak. Dalam pembagian tim tersebut, 1 tim bertujuan menyusun menara hingga tidak ada yang tersisa sambil menghindari tembakan bola yang dilemparkan oleh tim lain. Sedangkan tim lain bertugas untuk melemparkan bola ke tim lain yang bertugas menyusun menara. Pemain yang terkena lemparan bola maka akan dianggap gugur dan tidak boleh melanjutkan permainan lagi.

4. Permainan dimulai dengan menggulirkan bola kertas oleh tim penembak ke arah menara batu hingga berantakan (seperti melemparkan bola bowling), sementara tim penyusun menara bersiap-siap menyusun lagi kepingan batu tersebut sambil menghindar dari lemparan bola.

5. Permainan selesai jika menara selesai disusun atau anggota penyusun piramda semuanya gugur terkena lemparan bola.

6. Setelah selesai, posisi tim ditukar, yang tadinya sebagai tim penyusun berganti menjadi tim penembak, dan sebaliknya.
Permainan Tradisional Boi-boian (setelah dimodifikasi)

1. Menyiapkan kepingan kayu bergambar sebanyak jumlah tim pemain. (gambar ditempel berdasarkan materi pembelajaran yang akan disampaikan).

2. Menyiapkan 1 bola. Bola dibuat dari kertas yang diremas dan dibulatkan kemudian dibalut dengan selotip.

3. Tim dibagi menjadi dua kelompok, yaitu tim bermain dan tim berjaga. Setiap tim terdiri atas 2-15 anak (bergantung pada jumlah peserta didik yang terdapat dalam kelas). Dalam pembagian tim tersebut, 1 tim berperan sebagai tim pemain dan 1 tim yang lainnya berperan sebagai tim penjaga. Penentuan tim pemain dan tim penjaga ditentukan dengan melakukan suit.

4. Permainan dimulai dengan menggulirkan bola kertas oleh tim bermain ke arah menara hingga berantakan. Sebelum melakukan itu, tim pemain harus menjawab pertanyaan yang diberikan oleh tim penjaga berdasarkan gambar yang ditunjukkan oleh guru. Jika jawaban dari tim pemain benar, maka tim pemain berhak menghancurkan menara. Jika tidak mampu menjawab, maka tim pemain dinyatakan kalah dan berganti peran.

5. Tim pemaian menghancurkan menara, kemudian lari untuk mengecoh tim penjaga. Tim penjaga harus mengambil bola dan melemparkannya kepada salah satu anggota dari tim pemain. Tim yang terkena lemparan, harus menjawab pertanyaan yang diberikan oleh tim penjaga berdasarkan ilustrasi yang dibacakan oleh guru. Jika tim pemain yang kena lemparan tidak mampu menjawab, maka tim pemain dinyatakan kalah.

6. Setelah tim dapat menjawab pertanyaan dari tim penjaga, tim pemain harus menyususn menara dengan benar (1 anggota berhak menyusun 1 keping). Kesalahan penyusunan menara dapat menyebabkankekalahan pada tim.

7. Setelah tim pemain berhasil menyusun 
menara dengan tepat, maka point 1 untuk pemain dan permainan akan berulang dari awal lagi.

Unsur pola piker dapat ditanamkan melalui pendekatan saintifik yang tersatukan dalam konsep permainan tradisional boi-boian. Berikut adalah tabel keterkaitan antar unsur pola pikir sains, pendekatan saintifik dan permainan tradisional boi-boian:

Tabel 2: tabel keterkaitan antar unsur pola pikir sains, pendekatan saintifik dan permainan tradisional boi-boian

\begin{tabular}{|c|c|c|}
\hline $\begin{array}{l}\text { Unsur Pola } \\
\text { Pikir Sains }\end{array}$ & $\begin{array}{l}\text { Sintaks Pendekatan } \\
\text { Saintifik }\end{array}$ & $\begin{array}{l}\text { Penjelasan dalam Permainan Tradisional Boi- } \\
\text { Boian. }\end{array}$ \\
\hline $\begin{array}{l}\text { Scientific } \\
\text { point of view }\end{array}$ & Mengamati & $\begin{array}{l}\text { Kegiatan mengidentifikasi yang meliputi } \\
\text { kegiatan menyimak, } \\
\text { mendengarkan, } \\
\text { mengamati gambar, dan melihat atau } \\
\text { memperhatikan materi-materi yang disajikan } \\
\text { oleh guru melalui gambar ataupun ilustrasi } \\
\text { permasalahan. Kegiatan mengamati ini } \\
\text { dilakukan oleh semua peserta didik baik dalam } \\
\text { tim pemain maupun tim penjaga. Bahkan, } \\
\text { kegiatan mengamati dilatihkan oleh guru mulai } \\
\text { awal permainan (kegiatan mendengarkan dan } \\
\text { memperhatikan instruksi/ petunjuk pelaksanaan } \\
\text { permainan). }\end{array}$ \\
\hline $\begin{array}{l}\text { Scientific } \\
\text { question } \\
\text { issue }\end{array}$ & Menanya & $\begin{array}{l}\text { Sebelum permainan dimulai (ketika guru } \\
\text { memberikan arahan tentang cara permainan), } \\
\text { kegiatan menanya bisa muncul ketika peserta } \\
\text { didik mengajukan pertanyaan untuk } \\
\text { mendapatkan informasi tambahan yang ingin } \\
\text { diketahui atau hanya sekedar klarifikasi. } \\
\text { Sedangkan pada saat permainan berlangsung } \\
\text { kegiatan menanya dapat diamati pada saat tim } \\
\text { penjaga mengajukan pertanyan kepada tim } \\
\text { pemain berkaitan dengan gambar yang } \\
\text { ditunjukkan oleh guru ataupun ilustrasi yang } \\
\text { dibacakan oleh guru. Sedangkan pada tahapan } \\
\text { awal dalam permainan "kegiatan menanya" } \\
\text { juga bisa diamati melalui kegiatan berdiskusi } \\
\text { antar tim (baik dalam merumuskan pertanyaan } \\
\text { untuk tim lawan, maupun menjawab } \\
\text { pertanyaan dari tim lawan). }\end{array}$ \\
\hline $\begin{array}{l}\text { Scientific } \\
\text { information }\end{array}$ & $\begin{array}{l}\text { Mengumpulkan } \\
\text { informasi }\end{array}$ & $\begin{array}{l}\text { Kegiatan ini dapat diamati ketika antar anggota } \\
\text { tim mencoba untuk merumuskan pertanyaan } \\
\text { untuk tim lain dan mencoba merumuskan } \\
\text { jawaban untuk menjawab pertanyaan dari tim } \\
\text { lain. Selain itu, mereka juga mencoba mencari } \\
\text { tahu kepada guru atau pihak-pihak yang } \\
\text { mereka anggap lebih ahli untuk mendapatkan }\end{array}$ \\
\hline
\end{tabular}




\begin{tabular}{|c|c|c|}
\hline & & $\begin{array}{l}\text { informasi. Informasi - informasi yang mereka } \\
\text { dapatkan tersebut akan digunakan dalam } \\
\text { merumuskan jawaban dari tim lain. }\end{array}$ \\
\hline $\begin{array}{l}\text { Scientific } \\
\text { interpretation }\end{array}$ & $\begin{array}{l}\text { Mengasosiasikan / } \\
\text { Menalar }\end{array}$ & $\begin{array}{l}\text { Kegiatan yang dapat diamati yaitu ketika merka } \\
\text { mengumpulkan infomasi atau menghubungkan } \\
\text { fenomena yang ada atau informasi yang terkait } \\
\text { dalam rangka menemukan suatu pola untuk } \\
\text { kemudian menyimpulkannya. Kegiatan lain } \\
\text { yang dilihatkan disini adalah kegiatan diskusi } \\
\text { antar anggota dalam satu tim. }\end{array}$ \\
\hline $\begin{array}{l}\text { Scientific } \\
\text { concept }\end{array}$ & Mengomunikasikan & $\begin{array}{l}\text { Kegiatan membentuk / menentukan konsep } \\
\text { diakhir pembelajaran yang kemudian } \\
\text { dipaparkan di depan kelas / di depan teman } \\
\text { dalam satu tim. Perumusan konsep tersebut } \\
\text { tetap dibantu oleh guru dengan memberikan } \\
\text { kata kunci untuk memancing peserta didik } \\
\text { dalam merumuskannya. }\end{array}$ \\
\hline
\end{tabular}

Proses uji lapangan terhadap hasil pengembangan strategi permainan tradisional boi-boian dilaksanakan dengan menggunakan model eksperimen yang melibatkan kelas eksperimen dan kelas kontrol. Setelah diberikan perlakukan didapatkan data hasil posttest antara kelas eksperimen dan kelas kontrol sebagai berikut:

Tabel 3: Hasil Uji Normalitas Tests of Normality

\begin{tabular}{llccc}
\hline & & \multicolumn{3}{c}{ Shapiro-Wilk } \\
& \multicolumn{1}{c}{ Kelas } & Statistic & Df & Sig. \\
\hline nilai & kelas eksperimen & .974 & 23 & .786 \\
& kelas kontrol & .918 & 23 & .059 \\
\hline
\end{tabular}

a. Lilliefors Significance Correction

*. This is a lower bound of the true significance.

Berdasarkan tabel hasil uji normalitas tersebut nilai signifikansi untuk kelas eksperimen sebesar 0,786 dan untuk kelas kontrol sebesar 0,059. Karena nilai signifikasi untuk seluruh variabel penelitian tersebut lebih besar dari 0,05 (signifikansi kelas eksperimen 0,786 > 0,05 dan signifikansi kelas kontrol 0,059>0,05) maka dapat disimpulkan bahwa data pada kelas eksperimen dan kelas kontrol berdistribusi normal.

Tabel 4: Hasil Uji Homogenitas

Test of Homogeneity of Variances

Nilai

\begin{tabular}{cccc}
\hline Levene Statistic & $d f 1$ & $d f 2$ & Sig. \\
\hline 2.863 & 1 & 44 & .098 \\
\hline
\end{tabular}

Berdasarkan table hasil uji tersebut dapat diketahui bahwa signifikansi yang dihasilkan sebesar 0,098. Karena signifikansi yang dihasilkan lebih dari 0,05 maka dapat disimpulkan bahwa data yang didapatakan dari kedua kelompok dalam uji lapangan tersebut mempunyai varian yang sama (data homogen). 
Tabel 5: Hasil Uji Beda (Independent Sample T-test)

\begin{tabular}{|c|c|c|c|c|c|}
\hline \multirow{11}{*}{ 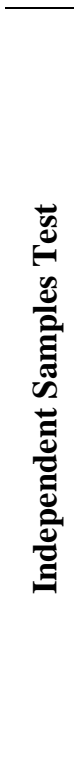 } & & & & \multicolumn{2}{|c|}{ Nilai } \\
\hline & & & & $\begin{array}{c}\text { Equal variances } \\
\text { assumed }\end{array}$ & $\begin{array}{c}\text { Equal } \\
\text { variances not } \\
\text { assumed }\end{array}$ \\
\hline & Levene's Test for Equality of & \multicolumn{2}{|l|}{$F$} & 3.788 & \\
\hline & Variances & \multicolumn{2}{|l|}{ Sig. } & 0.058 & \\
\hline & t-test for Equality of Means & \multicolumn{2}{|l|}{$T$} & 2.226 & 2.226 \\
\hline & & \multicolumn{2}{|l|}{$D f$} & 44 & 40.442 \\
\hline & & \multicolumn{2}{|c|}{ Sig. (2-tailed) } & 0.031 & 0.032 \\
\hline & & \multicolumn{2}{|c|}{ Mean Difference } & 3.391 & 3.391 \\
\hline & & \multicolumn{2}{|c|}{ Std. Error Difference } & 1.523 & 1.523 \\
\hline & & \multirow{2}{*}{$\begin{array}{l}95 \% \text { Confidence } \\
\text { Interval of the } \\
\text { Difference }\end{array}$} & Lower & 0.321 & 0.314 \\
\hline & & & Upper & 6.461 & 6.469 \\
\hline
\end{tabular}

Berdasarkan tabel hasil uji T tersebut, karena data yang diolah memiliki varian sama maka data yang dianalisis terdapat pada kolom nilai Equal variances assumed (data diasumsikan memiliki varian yang sama / homogen), dengan disajikan hipotesis pengujian sebagai berikut:

$\mathrm{H}_{0}$ : tidak ada perbedaan antara nilai evaluasi kelas kontrol dan kelas eksperimen $\mathrm{H}_{\mathrm{a}}$ : ada perbedaan antara nilai evaluasi kelas kontrol dan kelas eksperimen

Dari 46 jumlah sampel dalam penelitian tersebut, didapatkan $t$ tabel sebesar 2,015 . Oleh karena nilai t hitung > dari pada t tabel $(2,226>2,015)$ dan $\mathrm{P}$ value $(0,03<$ $0,05)$ maka $\mathrm{H}_{\mathrm{o}}$ dinyatakan ditolak. Berdasarkan hasil penghitungan tersebut terdapat perbedaan yang signifikan antara nilai kelas kontrol dan kelas eksperimen.Pada tabel Group Statistics terlihat bahwa rata-rata (mean) untuk kelas kontrol sebesar 78.96 sedangkan untuk kelas eksperimen sebesar 82.57, artinya bahwa nilai rata-rata kelas eksperimen lebih tinggi dari pada kelas kontrol. Perbedaan rata-rata (mean difference) sebesar 3,391 (82,57 - 78,96), dan perbedaan berkisar antara 0,321 sampai 6,461 (tertulis pada kolom lower dan upper).

\section{Pembahasan}

Strategi pembelajaran merupakan salah satu faktor penentu efektifitas proses pelaksanaan pembelajaran dalam lembaga pendidikan. Strategi-strategi pembelajaran baru yang dikembangkan merupakan bentuk upaya utuk menentukan kualitas peserta didik. Dalam konteks penelitian ini, strategi boi-boian merupakan salah satu strategi pembelajaran yang telah dikembangkan oleh peneliti dengan mengadopsi permainan tradisional boi-boian. Stategi tersebut juga menekankan pendekatan saintifik untuk menanamkan pola pikir sains dalam diri peserta didik. Strategi boi-boian ini sengaja dikembangkan untuk menjadi salah satu alternatif strategi pembelajaran di jenjang pendidikan dasar kelas atas (terutama dalam mata pelajaran / tema yang melibatkan kegiatan praktikum).

Penerapan strategi pembelajaran boi-boian dapat memberikan suasana baru selama proses pembelajaran berlangsung. Pelaksanaan strategi di ruang terbuka dapat mengikis suasana jenuh selama jam pelajaran. Stategi boi-boian yang memang dibuat dengan 
memperhatiakan karakteristik peserta didik pada tahapan operasional konkrit dan juga pada masa-masa bermain sambil belajar, dapat memacu mereka untuk bertindak aktif selama proses pembelajaran.

Unsur pola pikir sains yang ditanamkan melalui strategi pembelajaran tersebut meliputi: 1)Scientific point of view(dalam hal ini, peserta didik diajari untuk melakukan kegiatan mengidentifikasi yang meliputi kegiatan menyimak, membaca, mendengarkan dan mengamati); 2) Scientific question at issue (peserta didik dilatih untuk gemar bertanya dan tidak hanya sekedar menjawab pertanyaan. Peserta didik dilatih untuk bisa memilah pertanyaan-pertanyaan yang memerlukan jawaban pasti dan tidak. Pertanyaan yang diajukan oleh peserta didik harus mengarah pada pertanyaan kritis dan kreatif); 3) Scientific information(peserta didik dilatih untuk selalu mencari informasi-informasi up to date dalam merumuskan jawaban atas pertanyaan yang disajikan. Penggalian informasi bias melalui kegiatan bertanya kepada pihak yang lebih ahli ataupun dengan cara diskusi dengan teman sebayanya); 4) Scientific interpretation(dapat diamati ketika peserta didik mengumpulkan infomasi atau menghubungkan fenomena yang ada atau informasi yang terkait dalam rangka menemukan suatu pola untuk kemudian menyimpulkannya); 5)Scientific concept(kegiatan perumusan konsep yang juga dibantu oleh guru selama proses pembelajaran berlangsung).

Selama penerapan strategi pembelajaran boi-boian berlangsung, terdapat beberapa aktifitas yang harus dilakukan oleh peserta didik dengan dimediasi oleh guru. Di awal pembelajaran, setelah diberikannya pengantar materi oleh guru, peserta didik disajikan beberapa gambar untuk diamati. Hal yang ditekankan melalui kegiatan ini adalah bahwa dalam memecahkan suatu permasalahan, peserta didik harus melakukan observasi / pengamatan dari banyak sudut pandang. Peserta didik dibiasakan untuk memunculkan pertanyaan-pertanya kritis dan kreatif yang berkaitan dengan materi pembelajaran. Pertanyaan-pertanyaan tersebut kemudian diidentifikasi dalam sebuah diskusi bersama antar peserta didik. Di tahapan tersebut, unsur pola pikir sains yang diterapkan adalah peserta didik harus mengumpulkan informasi dari banyak pihak dan sumber yang relevan. Dalam hal ini, sikap percaya diri peserta didik untuk berargumentasi mulai dibangun dan dibiasakan. Selanjutnya, peserta didik harus menginferensikan informasi-informasi yang didapatkan menjadi sebuah jawaban. Jawaban tersebut harus dipaparkan dihadapan peserta didik lain. Setiap tahapan dalam rentetan kegiatan selama penerapan strategi boi-boian tersebut mencerminkan tahapantahapan untuk memecahkan permasalahan secara saintis.

\section{PENUTUP}

Urgensi permainan tradisional sebagai alternatif strategi pembelajaran adalah didasarkan pada (A) Hasil analisis kebutuhan guru dan peserta didik menunjukkan bahwa: strategi pembelajaran yang dipilih guru lebih menekankan pada metode ceramah, dikte dan hafalan sehingga belum mampu menanamkan pola pikir sains secara maksimal. Pola pikir peserta didik cenderung pasif, tidak terbiasa bertanya, malu berpendapat, belum mampu menyimpulkan dan kurang percaya diri; Guru belum pernah menerapkan strategi pembelajaran kooperatif; (B) Hasil validasi dan saran perbaikan dari para ahli terhadap pengembangan strategi dalam menanamkan pola pikir anak sekolah dasar (melalui pemeriksaan RPP) menunjukkan predikat baik dan amat baik baik (nilai berkisar antara 88,9 - 95,8). Beberapa saran perbaikan yang diberikan diantaranya adalah sintaks pendekatan saintifik harus ditonjolkan, kegiatan peserta didik dan guru harus spesifik, setiap kegiatan peserta didik harus mencerminkan KI yang 
sudah ditentukan; (C) Pengujian perbedaan hasil evaluasi dari penggunaan strategi dengan menggunakan rumus independent sample t-test menunjukkan hasil bahwa terdapat perbedaannilai yang signifikan antara kelas kontrol dan kelas eksperimen, yaitu dengan nilai $\mathrm{t}$ hitung $>$ dari pada $\mathrm{t}$ tabel $(2,226>2,015)$ dan $\mathrm{P}$ value $(0,03<0,05)$ denganrata-rata nilai kelas kontrol dan kelas eksperimen $(78.96<82.57)$. Sedangkan menurut hasil penilaian keaktifan peserta didik kelas eksperimen dinyatakan lebih aktif dalam hal mengamati, menanya, berargumen, mendengarkan dan kepercayaan diri.

\section{DAFTAR PUSTAKA}

Anik Ghufron. (2007). Panduan Penelitian dan Pengembangan Bidang Pendidikan dan Pembelajaran, Yogyakarta: Lembaga Penelitian UNY.

Arikunto, Suharsimi. (2010). Prosedur Penelitian Suatu Pendekatan Praktik, Jakarta: PT Rineka Cipta.

Atmojo, (2012) "Profil Keterampilan Proses Sains dan Apresiasi Siswa terhadap Profesi Pengrajin Tempe dalam Pembelajaran IPA Berbendekatan Etnosains", dalam Jurnal Pendidikan IPA Indonesia, Vol.2, No.2, 115-122.

Becker, Lee A. (2000). Effect Size Measures For Two Independent Groups, Journal : Effect Size Becker.

Fatonah, Siti. (2009) "Penggunaan Pendekatan Learning By Playing pada Pembelajaran Sains MI/SD”, dalam jurnal Al-Bidayah, Vol. 1, No.1, 47-58.

Hakimeh Akbari, MSc; etc. (2009) "The Effect of Traditional Games in Fundamental Motor Skill Development in 7-9 years old boys", Iran J Pediatr, Vol 19 (No 2), 123-129.

Hastjarjo, Dicky, Ringkasan Buku Cook \& Campbell (1979). (2008). QuasiExperimentation: Design \& Analysis Issues for Field Setting. Houghton Mifflin Co..

Ibda, Fatimah. (2015) Teori Perkembangan Kognitif: Teori Jean Piaget, Jurnal Intelektualita, Vol. 3, No. 1, 27-38.

Iswinarti, Endang Ekowarni , Adiyanti MG dan Rahmat Hidayat, (2016) "The Influence of traditional Game With Experiental Learning Methode on Social Competence", International Journal of Recent Scientific Research Vol. 7, Issue.4, 10147-10155.

Kemendikbud. (2013). Kurikulum 2013 Kompetensi Dasar Sekolah Dasar (SD)/Madrasah Ibtidaiyah (MI), Jakarta: Kemendikbud.

King, FJ, dkk, Higher Order Thinking Skill, (ttp: Educational Service Program, tt).

Mulyani, Sri. (2013). 45 Permainan Tradisional Anak Indonesia, Yogyakarta: Langensari Publishing.

Prastowo, Andi. (2015). Menyusun Rencana Pelaksanaan Pembelajaran (RPP) Tematik Terpadu Implementasi Kurikulum 2013 untuk SD/MI, Jakarta: Kencana.

Rao, Bhaskara dkk. (2008). Science Process Skills of School Ssudents, Delhi: Arora Offset Press.

Richard Paul, Linda Elder. (2012). The Thinker's Guide To Scientifik Thinking, France: Foundation for Critical Thinking.

Sanjaya, Wina. (2015). Perencanaan dan Desain Sistem Pembelajaran, Jakarta: Kencana.

Sitomurang, James R. (2015). "Penggunaan Game Theori dalam Ilmu Sosial." Jurnal Administrasi Bisnis, Vol.11, No.2, 160-172. 
Sri Sumarni. (2015). Pengembangan Model Pendidikan Karakter Barbasis Penguatan Modal Sosial Bagi Mahasiswa UIN Sunan Kalijaga, jurnal Pembangunan Pendidikan: Fondasi dan Aplikasi, vol. 3, no.1, 44-57.

Sugiyono. (2014). Cara Mudah Sripsi, Tesis dan Disertasi, Bandung: Alfabeta.

Sumantoro dkk. (2007). Silabus Sains, P.Sosial, Matematika, B.Indonesia untuk Kelas 3 $S D$, Yogyakarta: Kanisius.

Suroso Mukti Leksono, A. Syachruroji, Pipit Marianingsih, "Pengembangan Bahan Ajar Biologi Konservasi Berbasis Etnopedagogi." Jurnal Kependidikan Penelitian Inovasi Pembelajaran, Vol. 45, no.2, November 2015.

Suryana, Yaya, A. Rusdiana, Pendidikan Multikultural, Bandung: Pustaka Setya, 2015.

Syaiful Bahri Djamah, Aswan Zain. (2010). Strategi Belajar Mengajar,Jakarta: PT Rineka Cipta.

Tjana Kovacevic dan Sinisa Opick (Faculty of Teacher Education University of Zagreb). (2013). "Contribution of Traditional Game to the Quality of Student in Primary Education", Croatian Journal of Education, Vol.16; Sp.Ed.No.1, 95-112

Trianto. (2013). Model Pembelajaran Terpadu, Jakarta : PT Bumi Aksara.

Yamin, Martinis. (2013). Strategi dan Metode dalam Model Pembelajaran, Jakarta: GP Press Group.

Zainal Arifi. (2012). Penelitian Pendidikan Metode dan Paradigma Baru, Bandung: PT. Remaja Rosdakarya Offset.

Zuriah, Nurul. (2014). "Analisis Teoritik tentang Etnopedagogi Pendidikan Kewarganegaraan Sebagai Wahana Pendidikan Budaya dan Karakter bangsa di Perguruan Tinggi”, Jurnal Sosio Humanika, Vol. 7, No. 2, 174-188. 